\title{
PENGEMBANGAN MATERI AJAR ADAB BERMEDIA SOSIAL PADA KURIKULUM 2013
}

\author{
Budiyono \\ Institut Agama Islam Negeri Pontianak, Indonesia \\ budi2014.yono@gmail.com
}

\begin{abstract}
Cognitive human potential from through experiences, learning and the process of interaction and the almighty. Knowledge and experience forming personality can be according to life's need. The purpose of education is not only cognitive capacity building, but also attitude and moral learning. Paradigm this paper will dicuss the development of social media adab material into the curriculum 2013. Adab is moral consideration, in acting on the basis of consideration of rules, rules and norms apply. Having an awareness that everything ini this world has been arranged by the Creator. So, in acting able to be fair to all even creatures that are though not liked. The social sphere in the curriculum 2013 based on Minister of Education and Culture Regulation number 21 of 2016 about Content Standards for Primary core competencies for learning from elementary school (SD) and junior high school (SMP) and high school and vocational (SMK) which programs for strength social interaction behavior, such as; disciplined, confident, honest, responsif, pro-active, caring, polite and responsible. Social media is a means of social intercourse online in cyberspace. The users of social media communication interact with send messages, share (networking). The author on this paper offers an arrangement of teaching materials for curriculum in 2013 for integrating social media through the MUI Fatwa number 24 of 2017 about laws and gudelines on social Media as the source of teaching material.
\end{abstract}

Keywords: Adab, Social Media, Curriculum 2013

Abstrak: Potensi manusia yang kognitif dari melalui pengalaman, pembelajaran dan proses interaksi dan mahakuasa. Pengetahuan dan pengalaman membentuk kepribadian dapat sesuai dengan kebutuhan hidup. Tujuan pendidikan tidak hanya pengembangan kapasitas kognitif, tetapi juga sikap dan pembelajaran moral. Paradigma tulisan ini akan membahas pengembangan materi adab media sosial ke dalam kurikulum 2013. Adab adalah pertimbangan moral, dalam bertindak berdasarkan pertimbangan aturan, aturan dan norma berlaku. Memiliki kesadaran bahwa segala sesuatu di dunia ini telah diatur oleh Sang Pencipta. Jadi, dalam berakting mampu bersikap adil terhadap semua makhluk yang sekalipun tidak disukai. Lingkup sosial dalam kurikulum 2013 berdasarkan Peraturan Menteri Pendidikan dan Kebudayaan nomor 21 tahun 2016 tentang Standar Konten untuk kompetensi inti Sekolah Dasar untuk pembelajaran dari sekolah dasar (SD) dan sekolah menengah pertama (SMP) dan sekolah menengah dan kejuruan (SMK) program mana yang memperkuat perilaku interaksi sosial, seperti; disiplin, percaya diri, jujur, responsif, pro-aktif, peduli, sopan dan bertanggung jawab. Media sosial adalah sarana hubungan sosial online di dunia maya. Para pengguna komunikasi media sosial berinteraksi dengan mengirim pesan, berbagi (jaringan). Penulis pada makalah ini menawarkan pengaturan bahan ajar untuk kurikulum tahun 2013 untuk mengintegrasikan media sosial melalui Fatwa MUI nomor 24 tahun 2017 tentang undang-undang dan gudeline di Media sosial sebagai sumber bahan ajar.

Kata kunci: Adab, Media Sosial, Kurikulum 2013 


\section{A. Pendahuluan}

Para pekerja di bidang teknologi terus berinovasi agar dapat menghasilkan teknologi paling baik yang bisa dimanfaatkan seluas-luasnya bagi masyarakat. Salah satunya adalah produk pengembangan teknologi smartphone sebagai anugerah yang patut disyukuri dan merupakan karya monumental serta fungsional. Kedudukan manusia telah berubah tidak hanya sebagai konsumen, tetapi sekaligus produsen dan distributor informasi. Belakangan informasi yang tersaji dan dapat diakses dengan mudah melalui internet mulai memunculkan kekhawatiran, penyebabnya adalah semakin maraknya penyebaran informasi tidak benar (hoax), namun banyaknya informasi hoax tersebut menjadi sesuatu yang dianggap benar (faktual) oleh sebagian masyarakat yang lain, informasi hoax yang bertebaran di jagad maya didominasi ujaran kebencian dan isu agama. Menyikapi hal tersebut, Majelis Ulama Indonesia (MUI) sampai harus mengeluarkan Fatwa Nomor 24 Tahun 2017 tentang Hukum dan Pedoman Bermuamalah Melalui Media Sosial. ${ }^{1}$

Kali ini penulis tidak fokus membahas berita hoax, penulis ingin mengulas tentang perilaku masyarakat dalam memanfaatkan media sosial yang diperoleh melalui kemudahan akses internet tersebut, kemudian memformulasikan model tindakan maupun sikap yang seharusnya dilakukan masyarakat khususnya anakanak dan remaja usia sekolah. Sikap masyarakat terhadap media sosial sangat beragam, dengan tidak mengesampingkan manfaat positif, kita perlu mencermati perilaku segelintir remaja sejauh pengamatan penulis sangat meresahkan bahkan telah berdampak kurang kondusif dalam hubungan bermasyarakat. Proses politik Pemilu (Pilkada, Pileg dan Pilpres) menjadi salah satu pemicu munculnya ujaranujaran kebencian dan saling mencaci antar pendukung masing-masing, sebagian besar ketegangan tersebut bermula dari penyebaran informasi yang tidak valid, bahkan jika penerima informasi tersebut telah dapat mengidentifikasi ketidakbenaran sebuah informasi, tetap saja digunakan untuk menyerang pihak yang dianggap berlawanan.

${ }^{1}$ https:// mui.or.id/wp-content/ uploads/2017/06/Fatwa-No.24-Tahun-2017-Tentang-Hukumdan-Pedoman-Bermuamalah-Melalui-Media-Sosial.pdf. diakses 26 September 2018 
Pandangan psikologi humanism menyatakan, pendekatan ego berupa rasionalisasi terlihat dominan dalam penyebaran informasi yang dilakukan masyarakat, berbagai profesi, pendidikan maupun jenjang umur nyaris menggunakan pendekatan yang serupa karena naluri untuk mempertahankan diri atau "melukai" orang lain. ${ }^{2}$ Bayangkan, suatu informasi yang sudah dapat diidentifikasi sebagai berita bohong maupun benar sekalipun namun sudah tahu akan berimplikasi kurang baik, tetap disebarkan dengan motif tertentu. Kita memaksa diri untuk melakukan hal-hal yang mengesampingkan intelegensi dan hati nurani, padahal bisa bersikap jauh lebih baik dari itu. Secara sadar kita telah memancing bahkan menimbulkan kegaduhan di ruang publik, jika diidentifikasi apa kira-kira manfaat yang diperoleh setelah melakukan kegaduhan selain kemudharatan. Mungkin mendapatkan sesuatu yang penulis sebut dengan "kepuasan absurd", artinya merasa puas ketika melihat orang lain marah dan dipermalukan, sebaliknya akan membalas perlakuan yang lebih buruk jika diri sendiri merasa "terancam" maupun“diserang". Maka, dalam teori psikologi yang erat kaitannya dengan pendidikan yakni dibutuhkan kematangan kecerdasan interpersonal dan intrapersonal. Perlu upaya konstruktif dari pribadi masing-masing masyarakat untuk mendidik diri dan memberikan pendidikan tentang tata cara memanfaatkan media sosial.

Pengguna media sosial seolah-oleh tidak menyadari bahwa narasi yang disampaikan melalui dunia maya tersebut sejatinya berimplikasi terhadap kehidupan sosial di masyarakat. Nilai luhur bangsa Indonesia yang mengepankan kesopanan sesama anggota masyarakat, terlebih kepada yang lebih tua telah tertanam bahkan secara khusus diatur dalam kurikulum pendidikan di Indonesia. Pembelajaran tentang sikap saling menghormati ketika mennyikapi perbedaan tidak hanya dipahami secara teoritis, namun harus dimanifestasikan dalam perilaku kehidupan sehari. Sejatinya para tokoh bangsa ini telah mencontohkan bagaimana seharusnya manusia tetap mengedepankan adab tanpa mengesampingkan ilmu pengetahuan. Sebagaimana kisah yang patut diteladani yakni, kisah antara

2 Markus Utomo Sukendar, S.Sos, M.I.Kom. Psikologi Komunikasi; Teori dan Praktek. Yogyakarta, Deepublish, 2017. Hlm, 23. 
pemimpin Nahdlatul Ulama, KH Idham Cholid dan pemimpin Muhammadiyah, Buya Hamka ${ }^{3}$ ketika itu sedang melakukan perjalanan ke tanah suci. Selama perjalanan menuju tanah suci di dalam sebuah kapal laut, saat melaksanakan sholat subuh berjamaah, para pengikut Nadhlatul Ulama heran karena KH Idham Cholid yang mempunyai kebiasaan menggunakan doa qunut dalam kesehariannya, malah tidak memakai doa qunut saat Buya hamka dan sebagian pengikut Muhammadiyah menjadi makmumnya.

Demikian pula sebaliknya, saat Buya Hamka mengimami shalat subuh para pengikut Muhammadiyah merasa heran ketika Buya Hamka membaca doa qunut karena KH Idham Cholid dan sebagian pengikut NU menjadi makmumnya. Sikap toleransi yang dicontohkan oleh 2 (dua) Kyai besar tersebut merupakan manifestasi pembelajaran ta'dib/adab, beliau berdua tentu memiliki kompetensi keagamaan sangat mumpuni terkait amaliah masing-masing, namun betapa mulia sikap mereka dengan mengedepankan sikap menghormati meski terhadap sesuatu yang memiliki landasan kuat.

Pakar pendidikan Syed Muhammad al-Naquib al Attas ${ }^{4}$ misalnya, menyebut beberapa definisi untuk menggambarkan makna pendidikan Islam dengan beberapa istilah satu diantaranya Ta'dib. Menurutnya, ta'dib adalah bentuk bimbingan tentang pengenalan dan pengakuan atas kekuasaan, keagungan Tuhan dalam wujud yang nyata, pengenalan dan pengakuan dimaksud ditanamkan secara kesinambungan kepada manusia terkait tatanan penciptaan secara sistematis. Dapat pula diartikan suatu upaya mendidik melalui pembinaa dan penyempurnaan akhlaq atau budi pekerti peserta didik. Hal ini berarti orientasi ta' dib fokus terhadap upaya pembentukan pribadi yang berakhlaq mulia.

Potensi manusia secara kognitif didapat melalui pengalaman, belajar dan proses interaksi sesama manusia, alam serta kepada sang pencipta. Pengetahuan atau pengalaman membentuk kepribadian yang dapat dimanfaatkan sesuai kebutuhan kehidupan. Tujuan pendidikan tidak hanya pembinaan kapasitas secara

3 http://www.nu.or.id/post/read/64012/jaga-ukhuwah-belajarlah-pada-kh-idham-chaliddan-buya-hamka. diakses tanggal 26 September 2018

4 Wan Daud, Mohd Nor Wan. Filsafat dan Praktik Pendidikan Islam. Bandung : Mizan, 2003. Hlm, 107 
kognitif, namun perlu pembelajaran adab maupun moral. Ungkapan bijak "bagaikan sayur tanpa garam" sangat tepat jika disematkan terhadap kaitan antara ilmu dan adab ini, setinggi apa pun ilmu pengetahuan yang dikuasai namun terasa kurang bahkan bisa tidak ada artinya jika mengabaikan adab. Berangkat dari paradigma tersebut, tulisan ini akan membahas bagaimana pengembangan materi Adab bermedia sosial ke dalam Kurikulum 2013.

\section{B. Media Sosial}

Sosial Media adalah Sarana interaksi sosial secara daring di dunia maya berbasis internet. Interaksi bentuknya antara lain saling kirim pesan, saling berbagi (sharing) dan membangun hubungan pergaulan yakni jaringan (Networking). ${ }^{5}$ Melalui jaringan sosial menjadi situs bagi setiap orang membuat web page pribadi yang dapat terhubung dengan orang lain untuk membangun komunikasi dan berbagi informasi. Beberapa jaringan sosial paling populer antara lain Facebook, Myspace, WhatsApp, BBM, Youtube, Line, Instagram dan Twitter. Media cetak dan media broadcast masih bersifat tradisional, lain halnya operasional sosial media menggunakan jaringan internet. Sosial media memberi kontribusi dan timbal balik secara terbuka, menyampaikan komentar serta membagi informasi dalam waktu yang cepat dan tak terbatas. ${ }^{6}$

Sosial media mengalami perkembangan yang signifikan dari tahun ke tahun, jika pada tahun 2002 Friendster merajai sosial media karena hanya Friendster yang mendominasi sosial media di era tersebut, maka pada jaman sekarang telah banyak bermunculan sosial media dengan keunikan dan karakteristik masing-masing. Sejarah sosial media diawali pada era 70-an, yaitu ditemukannya sistem papan buletin yang memungkinkan untuk dapat berhubungan dengan orang lain menggunakan surat elektronik ataupun mengunggah dan mengunduh perangkat lunak, semua ini dilakukan masih dengan menggunakan saluran telepon dan terhubung dengan modem.

${ }^{5}$ Nasrullah, Rulli. 2015. Media Sosial : Perspektif Komunikasi, Budaya dan Sosioteknologi. Jakarta: Simbiosa Rekatama Media. Hlm. 5

${ }^{6}$ Briggs, ASA dan peter burke. sejarah sosial media dari gutenberg sampai internet. penerjemah: A. Rahman zainuddin, edisi I, jakarta : yayasan obor indonesia 2006.hal.10 
Sosial media pertama kali muncukl bernama sixdegree.com dan classmates.com berkembang pada tahun 1995 hingga 1999. Pada tahun yang sama muncul pula situs penyedia layanan blog pribadi, yaitu blogger. Melalui itus ini penggunanya yang disebut blogger ini dapat berkreasi untuk membuat hal tentang apapun. ${ }^{7}$ Kepopuleran friendster di tahun 2002 menjadi sosial media yang paling fenomenal dan banyak penggunanya. Barulah kemudian pada tahun 2003 sampai saat ini mulai bermunculan berbagai sosial media dengan kararakteristik dan kelebihan masingmasing, seperti Line, MySpace, Facebook, Twitter, Wiser, Google, WhatsApp, BBM, You Tube, Instagram dan sebagainya. ${ }^{8}$ Kini, Sosial media bisa dimanfaatkan berbagai kepentingan digital marketing, seperti Sosial Media Maintenance, Sosial Media Endorsemen dan Sosial Activation. Oleh karena itu, Digital Agency menjadikan media sebagai salah satu layanan yang ditawarkan.

Fasilitas menarik yang disediakan secara gratis oleh media sosial tersebut saat ini mulai digunakan kurang tepat oleh beberapa penggunanya. Berdasarkan laporan penelitian Brendan Nyhan and Jason Reifler (2012) dalam Nur Aksin berjudul Misinformation and Fact-checking: Research Findings From Sosial Science menyimpulkan, berita dan informasi yang bersifat faktual dengan penyajian data relatif akurat tetapi bertolak belakang dengan keyakinan cenderung ditolak. Sebaliknya, melalui perangkat media sosial, seseorang lebih senang mencari, membaca, dan menyebarkan berita yang sesuai dengan apa yang ia yakini meski berita itu belum jelas kebenarannya. Jika kemudian terbukti keliru dan menyadari sudah menyebarkan informasi salah, dianggapnya sebagai masalah kecil, bahkan seringkali tidak dianggap sebagai suatu kesalahan. Saat dikonfirmasi motif menyebarkannya, ia akan menyalahkan media lain yang dikutip sebagai sumber tidak valid dan cenderung menyalahkan wartawan atau penulis beritanya. 9

Media sosial turut andil dalam transformasi hubungan sosial manusia saat ini yang kemudian berperan besar terhadap perubahan perilaku interaksi sampai pola hubungan ekonomi masyarakat, media sosial nyaris menjelma menjadi kebutuhan

${ }^{7}$ Ibid, hlm. 11

8 Ibid,.hlm. 13 hlm, 121

9 Nur Aksin, Pandangan Islam Terhadap Pemanfaatan Media Sosial. Universitas PGRI Semarang. 
primer masyarakat semua usia dan profesi. Manfaatnya pun sangat terasa salah satunya tercipta peluang bisnis, kemudian seluruh pengguna media sosial leluasa mengungkapkan ide dan gagasan terhadap berbagai hal, mulai dari aktivitas seharihari hingga mengomentari situasi sosial terkini. Beberapa tahun terakhir kondisi "kebebasan" di media sosial mulai menimbulkan masalah sosial baru, pemicunya bisa beragam diantaranya; masalah pribadi maupun dengan orang lain yang diekspresikan di ruang media sosial, aktivitas masyarakat menyikapi gelaran politik (pilkada, pileg dan pilpres) yang kemudian memancing reaksi beragam dari pengguna media sosial lainnya sehingga muncul gesekan di ruang publik. Menyermati kondisi ini perlu upaya sistematis sebagai upaya meminimalisir dampak negatif yang timbul dari penggunaan media sosial yang kurang tepat. Menurut penulis lembaga pendidikan formal merupakan tempat paling bertanggung jawab dalam memberikan pembelajaran tata cara perilaku bermedia sosial melalui pengembangan bahan ajar di kurikulum yang berlaku yakni kurikulum 2013, secara tegas penulis akan ungkapkan pada bagian selanjutnya dalam tulisan ini.

\section{Pengembangan Kurikulum 2013}

Penyelenggaraan pendidikan sebagaimana yang diamanatkan dalam undangundang nomor 20 tahun 2003 tentang Sistem Pendidikan Nasional diharapkan dapat mewujudkan proses berkembangnya kualitas pribadi peserta didik sebagai generasi penerus bangsa di masa depan, yang diyakini akan menjadi faktor dominan bagi tumbuh kembangnya bangsa dan Negara Indonesia sepanjang jaman.

Dari sekian banyak unsur sumber daya yang memberikan kontribusi yang signifikan untuk mewujudkan proses berkembangnya kualitas potensi peserta didik. Jadi tidak dapat disangkal lagi bahwa kurikulum yang dikembangkan dengan berbasis pada kompetensi sangat diperlukan sebagai instrumen untuk mengarahkan peserta didik menjadi : 1) manusia berkualitas yang mampu dan proaktif menjawab tantangan jaman yang selalu berubah; 2) manusia terdidik yang beriman dan bertaqwa kepada Tuhan Yang Maha Esa, berakhlak mulia, sehat, berilmu, cakap, kreatif, mandiri; dan 3) warga Negara yang demokratis dan bertanggung jawab. 
Sebagaimana yang ditegaskan dalam pasal 1 ayat 19 UU Nomor 20 Tahun 2003 kurikulum adalah seperangkat rencana dan pengaturan mengenai tujuan, isi dan bahan pelajaran serta cara yang digunakan sebagai pedoman penyelenggaraan kegiatan pembelajaran untuk mencapai tujuan pendidikan tertentu. Pengembangan kurikulum 2013 merupakan langkah lanjutan pengembangan kurikulum berbasis Kompetensi yang telah dirintis pada tahun 2004 dan KTSP 2006 yang mencakup Kompetensi sikap, pengetahuan, dan keterampilan secara terpadu.

Pengembangan kurikulum didasarkan pada prinsip-prinsip sebagai berikut ${ }^{10}$ : 1) kurikulum bukan hanya merupakan sekumpulan daftar mata pelajaran yang hanya merupakan sumber materi pembelajaran untuk mencapai kompetensi; 2) kurikulum didasarkan pada kompetensi inti lulusan yang ditetapkan untuk satu satuan pendidikan, jenjang pendidikan, dan program pendidikan. Sesuai dengan kebijakan pemerintah mengenai wajib belajar 12 tahun. Maka kompetensi lulusan yang menjadi dasar pengembangan kurikulum adalah kemampuan yang harus dimiliki peserta didik setelah mengikuti proses pendidikan selama 12 Tahun; 3) kurikulum didasarkan pada model kurikulum berbasis kompetensi yang ditandai oleh pengembangan kompetensi berupa sikap, pengetahuan, keterampilan berfikir, keterampilan psikomotorik yang dikemas dalam berbagai mata pelajara. 4) kurikulum didasarkan pada prinsip bahwa setiap sikap, keterampilan dan pengetahuan yang dirumuskan dalam kurikulum berbentuk kompetensi dasar dapat dipelajari dan dikuasai setiap peserta didik (mastery learning) sesuai dengan kaidah kurikulum berbasis kompetensi; 5) kurikulum dikembangkan dengan memberikan kesempatan kepada peserta didik untuk mengembangkan perbedaan dalam kemampuan dan minat. 6) kurikulum berpusat pada potensi, perkembangan, kebutuhan dan kepentingan peserta didik dan lingkungannya. Kurikulum dikembangkan berdasarkan prinsip bahwa peserta didik berada pada posisi sentral dan aktif dalam belajar; 7) kurikulum harus tanggap terhadap perkembangan ilmu pengetahuan, budaya, teknologi dan seni; 8) kurikulum harus relevan dengan kebutuhan kehidupan; 9) kurikulum harus diarahkan kepada proses pengembangan,

10 Nur Irwantoro dan Yusuf Suryana. Kompetensi Pedagogik. Sidoarjo: Genta Group Production, 2016. hlm. 157-158 
pembudayaan dan pemberdayaan peserta didik yang berlangsung sepanjang hayat; 10) kurikulum didasarkan kepada kepentingan Nasional dan kepentingan daerah; 11) penilaian hasil belajar ditujukan untuk mengetahui dan memperbaiki pencapaian kompetensi. Instrument penilaian hasil belajar adalah alat untuk mengetahui kekurangan yang dimiliki setiap peserta didik atau kelompok peserta didik. Kekurangan tersebut harus segera diikuti dengan proses memperbaiki kekurangan dalam aspek hasil belajar yang dimiliki seorang atau sekelompok peserta didik.

Dalam ranah kompetensi sosial K_13 menekankan pada pembelajaran tentang interaksi sosial peserta didik sesuai tingkat perkembangannya dengan salah satu indikatornya yakni santun. Sikap santun sangat penting dalam melakukan interaksi sosial baik secara langsung maupun melalui media sosial, jenis interaksi tersebut tentu saja memiliki karakteristik yang berbeda tetapi perilaku atau adab tetap harus dikedepankan. Maka, landasan yuridis dalam pelaksanaan pembelajaran pada kurikulum 2013 perlu terus dikembangkan materi nya sesuai kebutuhan sosial kemasyarakatan. Pembelajaran kontekstual dilaksanakan untuk menjawab problem sosial yang terjadi di masyarakat, khususnya yang tidak boleh luput dari perhatian pendidik yakni perlu penguatan pembelajaran adab di media sosial.

\section{Bahan Ajar, Adab Bermedia Sosial}

Ranah sosial dalam kurikulum 2013 berdasarkan Peraturan Menteri Pendidikan Dan Kebudayaan Nomor 21 Tahun 2016 Tentang Standar Isi Pendidikan Dasar Dan Menengah memuat kompetensi inti pembelajaran dari tingkat sekolah dasar (SD), sekolah menengah pertama (SMP) dan sekolah menengah atas/kejuruan (SMA/ SMK) yang berisi program penguatan perilaku interaksi sosial seperti; disiplin, percaya diri, jujur, rensonsif, pro-aktif, peduli (gotong royong, kerjasama, toleran, damai), santun dan bertanggung jawab. Pada tahap sekolah dasar interaksi dimaksud yakni hubungan dengan keluarga, teman, guru, dan tetangga, dan negara. Memasuki tingkat menengah pertama, dapat berinterksi secara efektif sesuai dengan perkembangan anak di lingkungan, keluarga, sekolah, masyarakat dan lingkungan alam sekitar, bangsa, negara, dan kawasan regional dan kawasan internasional. Sedangkan, pada tingkat sekolah menengah atas/kejuruan diharapkan berkembang pada fase penghayatan dan implementasi prilaku melalui keteladanan, pemberian 
nasehat, penguatan, pembiasaan, dan pengkondisian secara berkesinambungan serta menunjukkan sikap sebagai bagian dari solusi atas berbagai permasalahan dalam berinteraksi secara efektif dengan lingkungan sosial dan alam serta dalam menempatkan diri sebagai cerminan bangsa dalam pergaulan dunia. ${ }^{11}$

Adab berasal dari bahasa arab adalah $a d d a b a$, bentuk masdar nya $t a^{\prime} d i b$ yang bila diterjemahkan ke dalam bahasa Indonesia mempunyai banyak arti, diantaranya mendidik, undangan penjamuan, kebudayaan, tata tertib sosial, kehalusan budi, ketertiban, kebiasaan yang baik, kepantasan, kemanusiaan dan kesusatraan. ${ }^{12}$ Para ulama klasik menerjemahkan dengan kepintaran, kecerdikan dan kepandaian. Sedangkan arti asalnya adalah sesuai dalam bahasa Indonesia adab berarti sopan, kesopanan, kebaikan budi (budi pekerti) dan kehalusan. Dari kata addaba bentuk perubahannya adalah adabun yang berarti pengetahuan dan wujud bersifat teratur secara hirarkis dikenal dan diakui secara hakikat sesuai dengan berbagai tingkat dan derajat tingkatan yang mencakup tempat dan potensi jasmaniah, intelektual maupun rohaniah seseorang. 13

Adab adalah disiplin tubuh, jiwa dan ruh, disiplin yang menegaskan pengenalan dan pengakuan tempat yang tepat dalam hubungannya dengan kemampuan dan potensi jasmaniah, intelektual dan ruhaniah, pengenalan dan pengakuan akan kenyataan bahwa ilmu dan wujud ditata secara hirarkis sesuai dengan berbagai tingkat dan derajatnya. Adab menunjukkan pengenalan dan pengakuan akan kondisi kehidupan, kedudukan dan tempat yang tepat, layak dan disiplin diri ketika berpartisipasi aktif dan sukarela dalam menjalankan peranan seseorang sesuai dengan pengenalan dan pengakuan itu, pemenuhannya dalam diri seseorang dan manusia secara keseluruhan mencerminkan kondisi keadilan. ${ }^{14}$

Syed al-Attas mengungkapkan bahwa orang yang terpelajar adalah orang baik. "Baik" yang dimaksud adalah adab dalam pengertian yang menyeluruh dan meliputi kehidupan spiritual dan material sesorang, yang berusaha menanamkan

${ }^{11}$ Lampiran Peraturan Menteri Pendidikan Dan Kebudayaan Nomor 21 Tahun 2016 Tentang Standar Isi Pendidikan Dasar Dan Menengah

12 Kemas Badaruddin, Filsafat Pendidikan Islam. Yogyakarta : Pustaka Pelajar, 2007. Hlm.30

${ }^{13}$ Ahmad Tafsir. Ilmu Pendidikan Dalam Perspektif Islam. Bandung : PT Remaja Rosdakarya. hlm. 
kualitas kebaikan yang diterimanya. Oleh karena itu, orang yang benar-benar terpelajar menurut perspektif Islam didefinisikan oleh al-Attas sebagai orang yang beradab. Dia mengatakan,

A good man is the one who is sincerely conscious of his responsibility towards the true God (insaf akan bertanggung jawab dirinya kepada Tuhannya yang hak); who understands and fulfills his obligations to himself and aothers in his society with justice (memahami serta menyelenggarakan penunaian keadilan terhadap dirinya dan diri-diri lain dalam masyarakat); who constantly strives to improve every aspect of himself towards perfection as a man of adab (insan adabi). ${ }^{15}$

Seseorang yang memiliki adab akan mampu mencegah dirinya dari kesalahan penilaian. Karena manusia tersebut memiliki kepintaran, kepandaian dan kecerdasan. Kecerdasan adalah kemampuan manusia untuk mengetahui dan melihat problem serta memecahkannya dengan baik. Dengan kecerdasan, orang mampu memberi sesuatu dengan benar dan tepat, ia akan mampu mendisiplinkan diri memikirkan terlebih dahulu segala perbuatannya. ${ }^{16}$ Secara sederhana adab penuh dengan pertimbangan moral, dalam bertindak atas dasar pertimbangan aturan, tata tertib dan norma yang berlaku. Memiliki kesadaran bahwa segala sesuatu di alam dunia ini telah ditata oleh sang Pencipta. Maka, dalam bertindak mampu berlaku adil terhadap semua bahkan kepada makhluk yang tidak disenangi sekalipun.

Berdasarkan pemaparan tentang konsep adab di atas, hal tersebut erat kaitannya dengan pola interaksi manusia termasuk dalam bermedia sosial sebagai makhluk sosial dan secara implementatif perilaku masyarakat harus dilatih mulai dari lembaga pendidikan yang merupakan faktor penting pembentukan moralnya, secara eksplisit Majelis Ulama Indonesia telah memberikan panduan perilaku/adab dalam bermumalah di Media Sosial melalui Fatwa MUI Nomor 24 Tahun 2017 tentang Hukum dan Pedoman Bermualah di Media Sosial, intinya sebagai berikut: ${ }^{17}$

15 Wan Mohd Nor Wan Daud, The Educational Philosophy and of Syed Muhammad Naquib Al-Attas: An Exposition of The Original Concept of Islamization, Kuala Lumpur: ISTAC, 1998. hlm. 133

${ }^{16}$ Kemas Badrudin, op.cit., hlm.31

${ }^{17}$ Op.cit 


\section{Karakteristik Media Sosial}

a. Media sosial merupakan sarana menjalin silaturahmi, menyampaikan informasi, sarana dakwah, media pembelajaran, rekreasi, dan untuk kegiatan positif di bidang agama, politik, ekonomi, dan sosial serta budaya.

b. Bermedia sosial harus dilakukan dengan memperhatikan dan tidak melanggar ketentuan agama dan peraturan perundan-gundangan.

c. Dalam menyikapi maupun membuat informasi di media sosial, antara lain; 1) Verifikasi konten/informasi media sosial. 2) Jika menemunkan konten yang baik sekalipun belum tentu benar, bisa jadi informasi tersebut bersumber dari rekayasa dengan tujuan tertentu; 3) Kebenaran informasi tidak selalu berbanding lurus dengan manfaatnya, meski informasi tersebut benar perlu dilakukan analisis saat akan disebarkan, kemungkinan baik-buruknya harus dipertimbangkan; 4) meski bermanfaat belum tentu cocok untuk disampaikan ke ranah publik; 5) verifikasi konten/informasi, karena yang benar itu tidak semua boleh dan pantas disebar ke ranah publik.

\section{Pedoman Verifikasi Konten/Informasi}

a. Memperoleh konten/informasi melalui media sosial (baik yang positif maupun negatif) harus memperhatikan manfaatnya saat akan menyebarkan dengan melakukan verifikasi dan klarifikasi/tabayyun.

b. Langkah-langkah dalam proses tabayyun sebagai berikut: 1) memastikan sumber informasi (sanad)nya dengan mempertimbangkan kepribadian, reputasi, kelayakan dan keterpercayaannya; 2) memastikan kebenaran (matan)nya, dengan mempertimbangkan isi dan tujuannya; 3) Memastikan konteks yang terdiri dari tempat dan waktu serta latar belakang saat informasi tersebut disampaikan.

c. Langkah-langkah memastikan kebenaran informasi antara lain : 1) mencari sumber terpercaya jika memungkinkan untuk ditemui; 2) mengkonfirmasi kepada pihak yang kompeten dan memiliki otoritas untuk mmberikan penjelasan. 
d. Hindari klarifikasi/tabayyun secara terbuka di ruang publik apalagi di media sosial sebelum kebenarannya dapat dikonfirmasikan untuk menghindari campur tangan pihak lain yang berpotensi memunculkan kegaduhan.

e. Klarifikasi/tabayyun tetap harus dilakukan terhadap konten/informasi yang berisi pujian, sanjungan, dan atau hal-hal positif tentang seseorang atau kelompok untuk memastikan kebenarannya.

\section{Pedoman Pembuatan Konten/Informasi}

a. Konten/informasi dibuat untuk memberikan manfaat bagi masyarakat terutama yang akan disampaikan ke ranah publik harus mengacu pada halhal sebagai berikut: 1) menggunakan kalimat, grafis, gambar, suara dan/atau yang simpel, mudah difahami, tidak multitafsir, dan tidak menyakiti orang lain; 2) sudah terverifikasi kebenarannya dengan merujuk pada pedoman verifikasi sebagaimana telah diungkapkan di atas; 3) pertimbangan penyajian informasi yang bermanfaat harus menjadi prioritas utama; 4) pembuatan konten/informasi bertujuan untuk dijadikan sarana amar ma"ruf nahi munkar secara luas; 5) memberikan dampak baik bagi penerima dalam mewujudkan kemaslahatan serta menghindarkan diri dari kerusakan; 6) menghindari pemilihan diksi yang provokatif serta tidak menghindari potensi munculnya reaksi kebencian dan permusuhan; 7) Kontennya tidak berisi hoax/berita bohong, fitnah, ghibah, namimah, bullying, gosip, ujaran kebencian, dan hal lain yang terlarang, baik secara agama maupun ketentuan peraturan perundangundangan; 8) menghindari potensi dorongan untuk berbuat hal-hal yang terlarang secara syar'i, seperti pornografi, visualisasi kekerasan yang terlarang, umpatan, dan provokasi; 9) Kontennya tidak berisi hal-hal pribadi yang tidak layak untuk disebarkan ke ranah publik.

b. Memastikan aspek manfaat konten/informasi antara lain dengan cara sebagai berikut: 1) konten/informasi dapat mendorong kepada kebaikan (al-birr) dan ketakwaan (altaqwa); 2) memperkuat persaudaraan (ukhuwwah) dan cinta kasih (mahabbah); 3) menjadi instrumen untuk meningkatkan ilmu pengetahuan; 4) Dapat mendorong untuk mematuhi ajaran Islam dengan 
menjalankan seluruh perintah-Nya dan menjauhi laranganNya; 5) tidak melahirkan kebencian (al-baghdla $a^{\mathrm{ec}}$ ) dan permusuhan (al-adawah).

c. Setiap muslim dilarang mencari-cari aib, kesalahan, dan atau hal yang tidak disukai oleh orang lain, baik individu maupun kelompok, kecuali untuk tujuan yang dibenarkan secara syar'i seperti untuk penegakan hukum atau mendamaikan orang yang bertikai (ishlah dzati al-bain).

d. Tidak boleh menjadikan penyediaan konten/informasi yang berisi tentang hoax, aib, ujaran kebencian, gosip, dan hal-hal lain sejenis terkait pribadi atau kelompok sebagai profesi untuk memperoleh keuntungan, baik ekonomi maupun non-ekonomi, seperti profesi buzzer yang mencari keutungan dari kegiatan terlarang tersebut.

\section{Pedoman Penyebaran Konten/Informasi}

a. Kriteria penyebaran konten/informasi harus mematuhi hal-hal diantaranya: 1) sudah terverifikasi kebenaran dari isi, sumber, waktu dan tempat, latar belakang serta konteks informasi disampaikan; 2) Bermanfaat, baik bagi semua pihak baik diri penyebar maupun bagi orang atau kelompok yang akan menerima informasi tersebut; 3) Bersifat umum, maksudnya informasi tersebut tepat dan layak diketahui oleh masyarakat dari seluruh lapisan sesuai dengan keragaman khalayak yang akan menjadi target sebaran informasi; 4) Tepat waktu dan tempat (muqtadlal hal), konteknya yaitu informasi yang akan disebar harus sesuai dengan waktu dan tempatnya karena informasi benar yang disampaikan pada waktu dan/atau tempat yang berbeda bisa memiliki perbedaan makna; 5) menghidari interpretasi makna dari khalayak, setiap informasi tidak boleh dipisahkan dari konteksnya apalagi sampai berupaya untuk melepaskan dari konteksnya dengan maksud tertentu akan memunculkan pengertian yang berbeda; 6) Hak penyebaran, orang yang menyebarkan memiliki hak menyebarkannya, tidak melanggar ketentuan seperti hak kekayaan intelektual dan tidak melanggar hak privasi.

b. Tidak boleh menyebarkan informasi yang berisi hoax, ghibah, fitnah, namimah, aib, ujaran kebencian, dan hal-hal lain sejenis yang tidak layak sebar kepada khalayak. 
c. Tidak boleh menyebarkan informasi untuk menutupi kesalahan, membenarkan yang salah dan menyalahkan yang benar, membangun opini agar seolah-olah berhasil dan sukses, dan tujuan menyembunyikan kebenaran serta menipu khalayak.

d. Tidak boleh menyebarkan konten yang bersifat pribadi ke khalayak, padahal konten tersebut diketahui tidak patut untuk disebarkan ke ranah publik, seperti ciuman suami istri dan pose foto tanpa menutup aurat.

e. Setiap orang yang memperoleh informasi tentang aib, kesalahan, dan atau hal yang tidak disukai oleh orang lain tidak boleh menyebarkannya kepada khalayak, meski dengan alasan tabayyun.

f. Setiap orang yang mengetahui adanya penyebaran informasi tentang aib, kesalahan, dan atau hal yang tidak disukai oleh orang lain harus melakukan pencegahan.

g. Pencegahan sebagaimana dimaksud dengan cara mengingatkan penyebar secara tertutup, menghapus informasi, serta mengingkari tindakan yang tidak benar tersebut.

h. Orang yang bersalah telah menyebarkan informasi hoax, ghibah, fitnah, namimah, aib, ujaran kebencian, dan hal-hal lain sejenis kepada khalayak, baik sengaja atau tidak tahu, harus bertaubat dengan meminta mapun kepada Allah (istighfar) serta meminta maaf kepada pihak yang dirugikan, menyesali perbuatannya dan komitmen tidak akan mengulangi.

Pedoman yang dimuat di dalam Fatwa tersebut secara lugas mengatur tata tertib atau adab bermedia sosial, sehingga perlu disampaikan kepada masyarakat mulai dari usia sekolah melalui pembelajaran di kelas. Dalam hukum Islam sendiri telah banyak kita ketahui bahwasannya, Islam di dalam aturannya tidak menutup diri dari berbagai perkembangan zaman yakni lebih dikenal dengan istlah "modernitas", dan dapat dikatakan pula Islam pada dasarnya malah menjembatani kita sebagai umatnya untuk bersikap terbuka dan dianjurkan supaya dapat memilah dan mengkomparasikan antara modernitas tersebut dengan apa-apa yang telah diajarkan dalam beberapa nash-Nya, yang pada akhirnya kita juga dapat menjadi 
umat yang maju dan lebih mengembangkan segala hal yang telah diberikan olehNya.

Beberapa pedoman yang dikemukakan di atas secara ideal merupakan upaya praksis dalam berinteraksi di media sosial, penyusunan pedoman berdasarkan alqur'an, Hadits dan pendapat ulama perlu diformulasikan secara sistematis ke dalam materi ajar khususnya pada mata pelajaran aqidah akhlak. Pengembangan materi adab tersebut bisa terintegrasi melalui materi pokok; perilaku saling menghormati, jujur, akhlak kepada sesama dan lain sebagainya, secara kontekstual dapat melengkapi dan menjawab kebutuhan sosial kemasyarakatan terutama adab di media sosial.

\section{E. Kesimpulan}

Hampir seluruh masyarakat di Indonesia menggunakan media sosial terutama Pelajar yang sangat dekat dengan kemajuan teknologi informasi dimaksud, kelompok pelajar ini lebih dikenal dengan istilah kaum millennial. Perkembangan media sosial tidak dapat dibatasi oleh ruang geografis, operasional media sosial juga tidak sulit, hanya dengan memanfaatkan smartphone ditunjang oleh paket data internet. Dewasa ini kecenderungan pengguna media sosial seolah-olah melakukan hal yang bebas nilai, padahal sikap yang ditunjukkan di ruang media sosial berimplikasi ke dalam kehidupan nyata.

Upaya untuk menjawab problem tersebut diperlukan tindakan sistematis dan terencana melalui lembaga Pendidikan formal, secara praksis penyusunan materi pembelajaran secara kontekstual sesuai kebutuhan jaman. Fatwa MUI tentang pedoman bermualah dapat menjadi salah satu sumber yang relevan bagi pendidik dalam mengembangkan bahan ajar untuk materi akhlak seperti; jujur, toleransi dan materi lain pada kurikulum 2013. Hal ini merupakan bentuk implementasi dari tujuan pendidikan itu sendiri yakni embelajaran tidak hanya menekankan pada aspek kognitif semata, aspek terpenting sebagai indikator keberhasilan pendidikan adalah sikap, tata nilai atau adabnya mencerminkan dan sejalan dengan peningkatan kognitif tersebut. 


\section{DAFTAR PUSTAKA}

Ahmad Tafsir. Ilmu Pendidikan Dalam Perspektif Islam. Bandung: Remaja Rosdakarya

Briggs, ASA dan peter burke, sejarah sosial media dari gutenberg sampai internet. penerjemah: A. Rahman zainuddin, edisi I, jakarta: yayasan obor Indonesia, 2006

https://mui.or.id/wp-content/uploads/2017/06/Fatwa-No.24-Tahun-2017-

Tentang-Hukum-dan-Pedoman-Bermuamalah-Melalui-Media-Sosial.pdf.

diakses 26 September 2018

http:/ / www.nu.or.id/post/read/64012/jaga-ukhuwah-belajarlah-pada-kh-idhamchalid-dan-buya-hamka. diakses tanggal 26 September 2018

Kemas Badaruddin. Filsafat Pendidikan Islam. Yogyakarta: Pustaka Pelajar, 2007.

Khoiron Rosyadi. Pendidikan Profetik, Yogyakarta: Pustaka Pelajar, 2004.

Lampiran Peraturan Menteri Pendidikan Dan Kebudayaan Nomor 21 Tahun 2016 Tentang Standar Isi Pendidikan Dasar Dan Menengah

Markus Utomo Sukendar. Psikologi Komunikasi; Teori dan Praktek. Yogyakarta, Deepublish, 2017.

Nasrullah, Rulli. Media Sosial : Perspektif Komunikasi, Budaya dan Sosioteknologi. Jakarta: Simbiosa Rekatama Media, 2015.

Nur Aksin, Pandangan Islam Terhadap Pemanfaatan Media Sosial. Jurnal Informatika UPGRIS. Vol 2 no.2 Desember 2016

Nur Irwantoro dan Yusuf Suryana. Kompetensi Pedagogik. Sidoarjo: Genta Group Production, 2016

Wan Mohd Nor Wan Daud. 1998. The Educational Philosophy and of Syed Muhammad Naquib Al-Attas: An Exposition of The Original Concept of Islamization, Kuala Lumpur: ISTAC

Wan Daud, Mohd Nor Wan. Filsafat dan Praktik Pendidikan Islam. Bandung: Mizan, 2003 